\title{
KOMUNIKASI, KECERDASAN EMOSIONAL DAN KINERJA PEGAWAI: STUDI EMPIRIS PADA DINAS SUMBERDAYA AIR BINA MARGA SULAWESI TENGGARA
}

\author{
Al Asy Ari Adnan Hakim, Selvi Diliyanti Rizki, Tri Mariati Sura \\ Fakultas Manejemen dan Bisnis Islam, Universitas Muhammadiyah Kendari, Kendari, Indonesia \\ Email: alasyariadnanhakim@febi.umkendari.ac.id, selvidr@febi.umkendari.ac.id
}

\section{A R T I C L E I N F O}

Article history:

Received: 16 June 2020

Accepted: 03 July 2020

Available online: 07 July 2020

Keywords:

Kecerdasan Emosional,

Komunikasi,

Kinerja Pegawai

\begin{abstract}
A B S T R A C T
Penelitian ini bertujuan untuk mengetahui pengaruh kecerdasan emosional dan kemampuan berkomunikasi terhadap kinerja pegawai pada Dinas Sumberdaya Air Bina Marga Provinsi Sulawesi Tenggara. Penelitian ini adalah penelitian kuantitatif kausalitas dengan subyek penelitian yaitu pegawai sebanyak 68 orang. Penelitian ini menggunakan metode analisis regresi linear berganda untuk menguji hipotesis. Hasil penelitian menemukan bahwa kecerdasan emosional dan komunikasi berpengaruh positif signifikan terhadap kinerja pegawai. Hal ini mengindikasikan bahwa peranan sumber daya manusia bagi suatu organisasi tidak hanya dapat ditentukan dari seberapa tingginya pendidikan yang dimiliki dan seberapa disiplinnya pegawai dalam bekerja, akan tetapi termasuk dari aspek yang lebih spesifik yakni kemampuan seorang pegawai dalam mengontrol emosionalnya dan juga kemampuan seorang pegawai dalam berkomunikasi.
\end{abstract}

\section{Pendahuluan}

Masih rendahnya kualitas sumberdaya manusia dan penanganannya merupakan salah satu masalah yang sering dihadapi oleh bangsa Indonesia. Pada umumnya sebagian besar organisasi yang ada percaya bahwa untuk mencapai sebuah keberhasilan, diperlukan adanya upaya dari kinerja individu secara maksimal. Kinerja individu merupakan patokan dasar dari keberhasilan suatu organisasi dalam menciptakan kinerja tim atau kelompoknya dan dalam menciptakan kinerja organisasinya.

Menurut Anwar Prabu (2017) mengemukakan bahwa kinerja pegawai merupakan hasil kerja secara kualitas dan kuantitas yang dicapai oleh seseorang pegawai dalam melaksanakan tugasnya sesuai dengan tanggungjawab yang berikan kepadanya. Lebih lanjut diuraikan pula oleh Yakub, Gunawan, \& Halim (2015) bahwa kinerja pegawai seharusnya mendapatkan perhatian yang serius dari pimpinan organisasi, mengingat kinerja pegawai akan menjadi sumber utama dari kinerja organisasi. Dengan kata lain, maju atau tidaknya suatu perusahaan akan sangat dipengaruhi oleh kinerja organisasi yang bersumber dari kinerja individu.

Diuraikan pula bahwa kinerja pegawai harus dikelola agar senantiasa terjadi pada posisi yang optimal. Kinerja yang baik dipengaruhi oleh tingkat kemampuan yang baik. Kemampuan seseorang dipengaruhi atas jenis pekerjaan dan keterampilan melakukannya (Yakub et al., 2015). Oleh 
karena itu, seorang pegawai harus dapat meningkatkan kemampuan dan keterampilannya.

Salah satu dari bentuk kemampuan yang harus ditingkatkan dalam mendukung peningkatan kinerja pegawai yakni pada komunikasi dan kemampuan untuk megontrol emosi pegawai. Menurut Robbins \& Judge (2008) bahwa perusahaan/organisasi tentunya terdiri dari banyak karyawan/pegawai baik bawahan maupun atasan yang mempunyai perilaku sendiri-sendiri seperti cekatan atau tanggap, hadir tepat waktu dan rajin. Dimana setiap individu saling terlibat dan berkomunikasi untuk mencapai tujuan yang diharapkan. Jika komunikasi terhambat maka karyawan/pegawai tidak dapat mencapai standar kinerja yang pada akhirnya berdampak terhadap pencapaian standar kinerja. Kemampuan komunikasi memelihara motivasi dengan memberikan penjelasan kepada para karyawan tentang apa yang harus dilakukan, seberapa baik mereka mengerjakannya dan apa yang dapat dilakukan untuk meningkatkan kinerja jika sedang berada dibawah standar.

Menurut Ismuhadjar (2006) bahwa komunikasi yang tercipta dalam suatu organisasi akan sangat mempengaruhi kinerja pegawai, karena semuanya tergantung pada kemampuan seseorang untuk mengkomunikasikan suatu informasi dan juga kemampuan seseorang untuk menerima pesan dan memberikan umpan balik terhadap informasi yang telah diterima.

Komunikasi sangat berperan dalam suatu organisasi, oleh karena itu guna mencapai tujuannya Newstrom dan Davis (2004) mengemukakan bahwa "apabila tidak ada komunikasi, maka para pegawai tidak dapat mengetahui apa yang dilakukan oleh rekan sekerjanya, pimpinan tidak dapat menerima masukan informasi dan tidak dapat memberikan instruksi. Robbins \& Judge (2008) menyebutkan bahwa komunikasi membantu perkembangan motiviasi dengan menjelaskan kepada para pegawai apa yang harus dilakukan, seberapa baik mereka bekerja dan apa yang dapat dikerjakan untuk memperbaiki kinerja yang dibawah standar.

Komunikasi dalam organisasi adalah suatu proses penyampaian informasi, ide-ide, diantara para anggota organisasi secara timbal- balik dalam rangka mencapai tujuan yang telah ditetapkan (Wursanto, 2003). Hal ini sangat penting apabila hanya terjadi satu arah saja yaitu dari pimpinan kepada bawahan atau sebaliknya maka komunikasi tidak dapat berjalan lancer. Sedangkan komunikasi horizontal mengalir antar anggota-anggota organisasi yang berada dalam level yang sama. Komunikasi ini digunakan dalam rangka koordinasi pelaksanaan tugas, saling membagi informasi dan pemecahan masalah-masalah. Komunikasi organisasi yang lancar akan memberikan rasa puas dalam diri pegawai dalam melaksanakan pekerjaannya. Komunikasi erat hubungannya dengan kinerja seorang pegawai, seperti yang diuraikan oleh Kusumastuti (2009) bahwa manfaat komunikasi salah satunya adalah meningkatkan kinerja terhadap organisasi.

Menurut Trihandini (2005) mengejelaskan kinerja pegawai tidak hanya dilihat dari kemampuan kerja yang sempurna tetapi juga kemampuan menguasai dan mengelola diri sendiri serta kemampuan dalam membina hubungan dengan orang lain. Kemampuan tersebut oleh Goleman (2005) disebut dengan emotional intelligence atau kecerdasan emosional.

Slovey dan Mayer (1990) dalam Goleman (2005) mendefinisikan kecerdasan emosional sebagai kemampuan memantau perasaan sosial yang melibatkan kemampuan pada orang lain, memilah-milah semuanya dan menggunakan informasi ini untuk membimbing pikiran dan tindakan.

Berdasarkan realitanya, dimana konteks kemampuan atau kecerdasan emosional seorang pegawai yang dilihat tidak hanya dari kemampuan untuk mengontrol emosi (pengendalian diri), kemampuan untuk memotivasi diri sendiri, kesanggupan untuk mengendalikan dorongan hati dan kemampuan untuk menyelesaikan konflik masih cenderung belum sepenuhnya dimiliki oleh pegawai. Terlebih lagi jika telah terjadi penumpukan beban kerja yang berlebihan dengan adanya tuntutan kerja yang harus selesai dalam waktu cepat, maka konteks kesanggupan untuk mengendalikan dorongan hati menjadi tidak terkendali.

Menurut Cooper dan Sawaf (2002) dalam Sani (2012) kecerdasan emosional mencakup 
pengendalian diri, semangat dan ketekunan serta kemampuan untuk memotivasi diri sendiri dan bertahan menghadapi frustasi, kesanggupan untuk mengendalikan dorongan hati dan emosi, tidak melebih-lebihkan kesenangan mengatur suasana hati, dan menjaga agar beban stress tidak melumpuhkan kemampuan berpikir, untuk membaca perasaan terdalam orang lain (empati), untuk memelihara hubungan dengan sebaik-baiknya, kemampuan untuk menyelesaikan konflik serta untuk memimpin orang-orang yang dikuasai dorongan hati yang kurang memiliki kendali diri. Kedri (2011) dalam Kahtani (2013) mengemukakan bahwa kecerdasan emosional juga akan menolong seseorang menjadi lebih seimbang dalam intelektual, emosi, fisik dan spiritual.

Hal ini sejalan dengan Fenomena yang terjadi pada Dinas Sumberdaya Air Bina Marga Provinsi Sulawesi Tenggara, dimana masih adanya beberapa pegawai yang sering kali kurang memahami antara apa yang disampaikan dan apa yang akan mereka kerjakan atau dalam kata lain pegawai secara nyata belum mampu bisa untuk menafsirkan pengartian kode-kode pesan yang disampaikan, baik itu antara pimpinan dan pegawai, pegawai dan pegawai maupun antara pegawai dan klien. Terlebih pula dalam penyampaiannya yang masih belum sepenuhnya mampu terekspresikan dalam pesan yang pada akhirnya berakibat pada adanya penurunan kinerja pegawai.

Penelitian terkait komunikasi dan kecerdasan emosional terhadap kinerja pegawai pada dasarnya telah banyak dikemukakan oleh para ahli dan beberapa peneliti lainnya. Meskipun demikian, belum ada hasil yang cukup pasti untuk bisa menjustifikasi bahwa komunikasi dan kecerdasan emosional dapat berpengaruh terhadap kinerja pegawai. Hal ini sebagaimana yang dikemukakan oleh Romantik (2014) dalam penelitiannya mengemukakan bahwa terdapat perbedaan pengaruh antara kecerdasan emosional dan komunikasi terhadap kinerja karyawan, dimana ditemukan adanya pengaruh tidak signifikan atara kecerdasan emosional terhadap kinerja karyawan. Sedangkan lain halnya untuk kemampuan komunikasi yang mana berdasarkan hasilnya ditemukan adanya pengaruh positif signifikan terhadap kinerja karyawan. Arie Soetti \& Ayu Istiqomah (2016) mengemukakan pula bahwa kecerdasan emosional berpengaruh negative tidak signifikan terhadap kinerja karyawan.

Sehingga berdasarkan hal tersebut, peneltian ini bertujuan untuk menguji pengaruh kecerdasan emosional dan komunikasi terhadap kinerja pegawai. Hasil penelitian ini diharapkan bisa memberikan kontribusi dalam pengembangan literature serta memberikan implikasi praktis kepada organisasi sektor publik untuk membuat kebijakan tentang pengembangan sumberdaya manusia agar kinerja pegawai dapat ditingkatkan.

\section{Tinjauan Pustaka dan Pengembangan Hipotesis}

\subsection{Pengaruh Komunikasi Terhadap Kinerja Pegawai \\ Zorn dan Violante (1996) dalam Payne} 2005) mendapati hubungan yang signifikan antara kemampuan komunikasi pada mobilitas ke atas dan tingkat pekerjaan. Individuindividu dengan sistem konstruk yang lebih berdiferensiasi dan tingkat komunikasi persuasive terfokus pada seseorang yang mencapai tingkat pekerjaan, gaji dan prestasi karir keuangan yang lebih tinggi.

Tingkat keterampilan komunikasi yang tinggi tidak hanya dikaitkan dengan keberhasilan organisasi para manajer dan supervisior, tetapi juga karyawan. Scudder \& Guinan (1989) mendapati hubungan signifikan antara kemampuan karyawan dalam memelihara komunikasi, memeliharan hubungan user dengan rating supervisor atas kinerjanya.

Lebih lanjut, Wong \& Law (2002) menemukan bahwa komunikasi yang positif diperlukan untuk menunjang keberhasilan dalam lingkungan kerja atau dengan kata lain, komunikasi yang efektif berpengaruh dalam meningkatkan upaya-upaya koordinasi yang selanjutnya akan meningkatkan kinerja tim.

Lakoy (2015), Yakub et al., (2015), Femi, (2014) dan Duwit (2015) dalam penelitiannya mengemukakan bahwa komunikasi berpengaruh signifikan terhadap kinerja pegawai. Lebih lanjut diuraikan pula bahwa 
komunikasi merupakan salah satu dari dua variabel lainnya yang dominan pengaruhnya terhadap kinerja pegawai.
H1: Komunikasi
berpengaruh positif signifikan terhadap kinerja pegawai

\subsection{Pengaruh Kecerdasan Emosional} Terhadap Kinerja Pegawai

Hasil penelitian McClelland, Hunter dan Schmid (1973) menunjukkan indikasi bahwa faktor domain yang menentukan keberhasilan karir bukanlah kecerdasan otak, melainkan seperangkat kecerdasan lainnya yang kemudian dipopulerkan oleh Goleman sebagai kecerdasan emosional. Penelitian lebih lanjut yang dilakukan oleh McClelland menyatakan bahwa kemampuan akademik bawaan, nilai rapor dan predikat kelulusan pendidikan tinggi tidak memprediksi seberapa baik kinerja seseorang sesudah bekerja atau seberapat tinggi sukses yang dicapai selama hidup.

Hasil penelitian Goleman (2005) menunjukkan bahwa kemampuan kecerdasan emosional adalah pendorong kinerja puncak. Kemampuan-kemampuan kognitif seperti big picture thinking dan long term vision juga penting, tetapi ketikan dibandingkan antara kemampuan teknikan, IQ dan kecerdasan emosional sebagai penentu kinerja yang cemerlang, maka kecerdasan emosional menduduki porsi lebih penting dua kali dibandingkan dengan yang lain pada seluruh tingkat jabatan.

Sejalan dengan hasil penelitian Harmont (2000) menunjukkan bahwa pemberian umpan balik terhadap penilaian kinerja karyawan oleh atasan, jika tidak menggunakan dasar kecerdasan emosional justru akan menurunkan motivasi kerja dan kinerja karyawan. Atasan yang mempunyai keterampilan kecerdasan emosional yang baik, akan mampu membangkitkan motivasi dan kerja dan pembenahan diri karyawan yang positif.

Naseer, Chishti, Rahman, \& Jumani (2011), Pudhag Wangi \& Faslah (2013) dan Susi Hendriani, Yulia Efni (2013) dalam penelitiannya, mengemukakan bahwa kecerdasan emosional memiliki dampak positif terhadap kinerja tim. Bahkan diuraikan lebih lanjut bahwa kecerdasan emosional terbukti menjadi faktor pendukung utama kesuksesan dan khususnya memainkan peran penting dalam mengembangkan kemampuan tenaga kerja yang pada akhirnya berdampak terhadap kinerja.

H2: Kecerdasan emosional berpengaruh positif signifikan terhadap kinerja pegawai

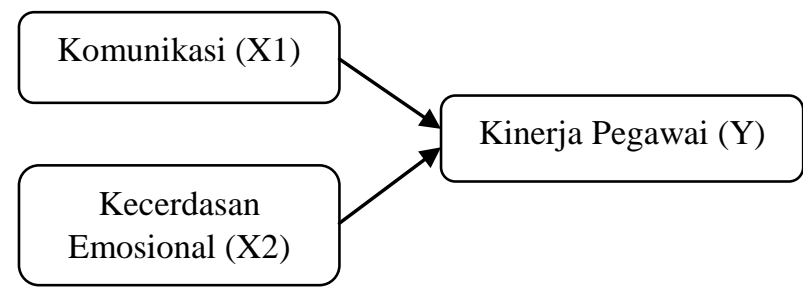

Gambar 1. Model Penelitian

\section{Metode Penelitian}

Penelitian ini merupakan penelitian kuantitatif, dengan obyek penelitian adalah Dinas Sumberdaya Air Bina Marga Provinsi Sulawesi Tenggara. Pada penelitian ini yang menjadi subyek penelitian adalah pegawai tetap yakni sebesar 68 pegawai. Adapun alat analisis yang digunakan adalah regresi linear berganda.

Pada penelitian ini komunikasi diukur menggunakan 7 indikator sebagaimana yang diuraikan oleh Ivancevich, et. al. (2007) yang meliputi : komunikator, encoding, message chanel/medium, receiver, feedback dan noise. Sedangkan untuk kecerdasan emosional diukur menggunakan 5 indikator sebagaimana yang diuraikan oleh Goleman (2005) meliputi : pengenalan diri, pengendalian diri, motivasi, empati dan keterampilan sosial.

Adapun untuk kinerja pegawai dalam penelitian ini diukur dengan menggunakan 5 indikator sebagaimana yang diuraikan Flippo (2009) yakni meliputi : pengetahuan tentang pekerjaan, mutu/kualitas kerja, kuantitas kerja, ketangguhan dan sikap.

\section{Hasil Penelitian dan Pembahasan}

Berdasarkan hasil penelitian terkait pengaruh komunikasi dan kecerdasan emosional terhadap kinerja pegawai ditemukan hasil sebagai berikut:

Tabel 1: Hasil Uji Regresi Linier Berganda

\begin{tabular}{ccccccc}
\hline \multirow{5}{*}{ Model } & \multicolumn{2}{c}{ Unstandardized } \\
& Coefficients & T & Sig & F & Sig \\
& Beta & Std. E & & & & \\
\hline (Constant) & 3,670 & 0,632 & 5,810 & 0,000 & & \\
X1 & 0,347 & 0,169 & 2,051 & 0,044 & 4,794 & 0,011 \\
X2 & 0,511 & 0,165 & 3,093 & 0,003 & & \\
\hline
\end{tabular}




\subsection{Pengaruh Komunikasi dan Kecerdasan Emosional Terhadap Kinerja Pegawai \\ Hasil dan Pembahasan menampilkan} analisis data untuk menjawab rumusan masalah atau pertanyaan penetilian. Pembahasan tentang tabel, grafik atau gambar tidak boleh menuliskan ulang isi grafik dalam bentuk kalimat, tetapi harus dijelaskan maknanya.

Berdasarkan hasil penelitian yang telah diuraikan sebelumnya yakni mengenai pengaruh kecerdasan emosional dan komunikasi terhadap kinerja pegawai pada Dinas Sumberdaya Air Bina Marga Provinsi Sulawesi Tenggara, ditemukan bahwa kecerdasan emosional dan komunikasi berpengaruh positif signifikan terhadap kinerja pegawai yang berarti bahwa setiap adanya peningkatan yang terjadi pada kecerdasan emosional pegawai dan komunikasi pegawai maka kinerja pegawai pada Dinas Sumberdaya Air Bina Marga Provinsi Sulawesi Tenggara akan ikut mengalami peningkatan.

Hal ini dimaksudkan bahwa pegawai akan memiliki kinerja kerja yang sangat baik, jika setiap pegawai memiliki tingkat kecerdasan emosional dan komunikasi yang baik. Kecerdasan emosional ini antara lain berupa adanya pengenal diri, pengendalian diri secara emosional dalam bekerja, mampu untuk memotivasi diri sendiri, memiliki rasa empati dan juga didukung adanya keterampilan sosial. Sedangkan dalam hal komunikasi antara lain : pegawai mampu untuk menyampaikan informasi yang baik dan benar serta akurat, pegawai mampu untuk menangkap dan memahami kode yang diberikan pegawai lain dalam betuk pesan, pegawai mampu menyampaikan pesan secara verbal maupun non verbal, mampu menggunakan media informasi yang tepat dan efektif, pegawai memiliki daya tanggap yang cepat dalam mengaplikasikan informasi yang diterima serta adanya umpan balik yang diberikan pegawai kepada pegawai lain.

Konteks hubungan antara kecerdasan emosional dan komunikasi terhadap kinerja pegawai ini, secara nyata pula tergambarkan di Dinas Sumberdaya Air Bina Marga Provinsi Sulawesi Tenggara, dimana secara rata-rata pegawai telah mampu untuk mengaplikasikan emosionalnya dengan secara baik yakni pegawai mampu untuk mengendalikan emosionalnya jika dihadapkan pada suatu masalah, pegawai juga memiliki kehati-hatian dalam bekerja guna menjaga tidak terjadinya kesalahan yang dapat mempengaruhi kinerja organisasi, pegawai mampu memegang komitmen organisasi dengan secara baik serta pegawai memberikan bantuannya kepada pegawai lain agar mampu berkembang guna meningkatkan kinerja organisasi seperti dengan memberikan kesempatan untuk mengikuti latihan atau melakukan sharing of knowledge maupun transfer of training kepada pegawai yang lain.

Sementara itu jika ditinjau dari sisi komunikasi juga terlihat bahwa pegawai dalam realitanya memiliki kemampuan bertutur bahasa yang baik dan benar, memberikan informasi-informasi yang akurat kepada pegawai lain sehingga tidak menimbulkan miss comunication, pegawai juga secara nyata telah mampu untuk memahami dengan baik maksud dan isi informasi yang diberikan baik itu antara sesama pegawai maupun antara atasan kepada pegawai. Sehingga hal ini tentunya akan berpengaruh terhadap kinerja pegawai secara nyata khususnya tanpa terkecuali pada Dinas Sumberdaya Air Bina Marga Provinsi Sulawesi Tenggara.

Hasil penelitian ini sejalan dengan hasil hipotesis yang telah diuraikan pada pembahasan sebelumnya yang menyatakan adanya pengaruh positif signifikan antara kecerdasan emosional dan komunikasi pegawai terhadap kinerja pegawai. Lebih lanjut diuraikan pula bahwa temuan ini sekaligus memperkuat kajian teoritis dan penelitian terdahulu mengenai kecerdasan emosional dan komunikasi terhadap kinerja pegawai.

Sebagaimana yang diuraikan oleh Yakub et al., (2015) dalam penelitiannya yang mengemukakan bahwa komunikasi dan kecerdasan emosional secara simultan dan parsial berpengaruh positif terhadap kinerja pegawai. Sebagian keterampilan komunikasi merupakan faktor dominan yang mempengaruhi kinerja pegawai, dimana nilai koefeisen determinasi ( $\mathrm{R}$ Square) yang diperoleh dalam penelitian ini adalah sebesar 60,4 persen. 
Diuraikan pula oleh Susi Hendriani, Yulia Efni (2013) dalam penelitiannya "Kecerdasan Emosional, Komunikasi, Komitment dan Kinerja Pegawai", menunjukkan bahwa kecerdasan emosional dan komunikasi memiliki korelasi yang signifikan dari 0.38 dengan komitmen dan memiliki korelasi yang signifikan dengan kinerja. Hal serupa juga diuraikan oleh Pudhag Wangi \& Faslah (2013) dalam penelitiannya yang mengemukakan bahwa terdapat hubungan positif antara komunikasi dan kecerdasan emosional terhadap kinerja pegawai. Semakin baik komunikasi antarpribadi yang terjalin diantara pegawai, maka kinerja pegawai meningkat. Begitu juga semakin tinggi tingkat kecerdasan emosional, maka kinerja pada pegawaiakan meningkat.

Adanya pengaruh positif signifikan antara kecerdasan emosional dan komunikasi mengindikasikan bahwa peranan SDM bagi suatu organisasi tidak hanya dapat ditentukan dari seberapa tingginya pendidikan yang dimiliki dan seberapa disiplinnya pegawai dalam bekerja, akan tetapi termasuk dari aspek yang lebih spesifik yakni kemampuan seorang pegawai dalam mengontrol emosionalnya dan juga kemampuan seorang pegawai dalam berkomunikasi.

Sering kali bagi suatu organisasi untuk mengabaikan aspek emosional dan komunikasi. Padahal jika ditinjau lebih mendalam, emosional dan komunikasi merupakan variabel dominan. Yakub et al., (2015) bahwa emosi merupakan hasil dari interaksi antara pikiran, perubahan fisiologis dan perilaku. Oleh sebab itu, diperlukan kecerdasan dalam mengelola emosi. Pegawai yang memiliki kecerdasan emosional yang tinggi dapat dilihat dari sikapnya yang tidak cepat marah atas sikap orang lain kepadanya, tidak tergesa-gesa dalam melakukan pekerjaan, namum pekerjaan dikerjakan sesuai dengan skedul yang sudah direncanakan, proaktif terhadap ide orang lain dan sikapsikap lainnya.

Semua orang akan merasa nyaman, apabila berhadapan dengan seseorang yang memiliki kecerdasan emosi yang baik. Dengan demikian, seseorang tersebut akan memiliki banyak hubungan yang baik kepada sesama karyawan lainnya dan kepada atasannya dan hal ini akan berimplikasi pada kinerja. Jadi, semakin tinggi kecerdasan emosi seorang pegawai akan semakin tinggi pula kinerja pegawai tersebut.

Hal serupa juga untuk komunikasi, menurut Robbins \& Judge (2008) berpendapat bahwa perusahaan/organisasi tentunya terdiri dari banyak karyawanb/pegawai baik bawahan maupun atasan yang mempunyai perilaku sendiri-sendiri seperti cekatan atau tanggap, hadir tepat waktu dan rajin. Dimana setiap individu saling terlibat dan berkomunikasi untuk mencapai tujuan yang diharapkan. Jika komunikasi terhambat maka karyawan/pegawai tidak dapat mencapai standar kinerja yang pada akhirnya berdampak terhadap pencapaian standar kinerja. Kemampuan komunikasi memelihara motivasi dengan memberikan penjelasan kepada para karyawan tentang apa yang harus dilakukan, seberapa baik mereka mengerjakannya dan apa yang dapat dilakukan untuk meningkatkan kinerja jika sedang berada dibawah standar.

Sehingga berdasarkan hal ini, maka jelas dapat dikemukakan bahwa kemampuan komunikasi memang merupakan suatu hal yang sangat fundamental bagi kehidupan manusia.Dengan mampu berkomunikasi yang baik, maka diharapkan bisa membentuk suatu hubungan yakni saling pengertian antara pegawai, menumbuhkan persahabatan, memelihara kasih sayang dan mengembangkan karir. Sebaliknya dengan kemampuan komunikasi yang buruk maka akan berdampak terhadap suatu hubungan yang negative antara sesame pegawai.

\subsection{Pengaruh Komunikasi Terhadap Kinerja Pegawai}

Berdasarkan hasil penelitian yang telah diuraikan sebelumnya mengenai pengaruh komunikasi terhadap kinerja pegawai pada Dinas Sumberdaya Air Bina Marga Provinsi Sulawesi Tenggara, maka ditemukan bahwa komunikasi berpengaruh positif signifikan terhadap kinerja pegawai.Hasil penelitian ini sejalan dengan penelitian terdahulu yang mengemukakan bahwa adanya pengaruh positif signifikan antara komunikasi terhadap kinerja pegawai. Menurut (Romantik, 2014) dalam penelitiannya mengemukakan bahwa terdapat perbedaan pengaruh antara 
kecerdasan emosional dan komunikasi terhadap kinerja karyawan, dimana ditemukan adanya pengaruh tidak signifikan atara kecerdasan emosional terhadap kinerja karyawan. Sedangkan lain halnya untuk kemampuan komunikasi yang mana berdasarkan hasilnya ditemukan adanya pengaruh positif signifikan terhadap kinerja karyawan.

Panuju (2001) mengemukakan bahwa komunikasi adalah sistem aliran yang menghubungkan kinerja antar bagian dalam organisasi sehingga menghasilkan suatu sinergi. Tujuan komunikasi adalah menciptakan pemahaman bersama atau mengubah persepsi, bahkan perilaku. Lakoy (2015) mengemukakan bahwa komunikasi, kerjasama kelompok dan kreativitas secara serentak berpengaruh signifikan terhadap kinerja karyawan di Hotel Aryaduta Manado. Lebih lanjut diuraikan pula bahwa komunikasi merupakan salah satu dari dua variabel lainnya yang dominan pengaruhnya terhadap kinerja karyawan.

Hal serupa diuraikan pula oleh Yakub et al (2015) dalam penelitiannya mengemukakan bahwa kemampuan komunikasi dan kecerdasan emosional secara simultan dan parsial berpengaruh positif terhadap kinerja karyawan. Sebagian keterampilan komunikasi merupakan faktor dominan yang mempengaruhi kinerja karyawan, dimana nilai koefeisen determinasi ( $\mathrm{R}$ Square) yang diperoleh dalam penelitian ini adalah sebesar 60,4 persen. Hal serupa juga diuraikan oleh Pudhag Wangi \& Faslah (2013), Duwit, 2015), Susi Hendriani, Yulia Efni (2013) yang mengemukakan bahwa antara kecerdasan emosional dan komunikasi berpengaruh positif signifikan terhadap kinerja pegawai.

Katz \& Kahn (1978) mengemukakan yang merupakan hal utama dari komunikasi adalah pertukaran informasi dan penyampaian makna suatu system sosial atau organisasi.Komunikasi tidak hanya menyampaikan informasi atau pesan saja, tetapi komunikasi dilakukan seseorang dengan pihak lainnya dalam upaya untuk membentuk suatu makna serta mengemban harapanharapannya.Dengan demikian komunikasi mempunyai peranan yang sangat penting dalam menentukan efektif dan tidak efektifnya, orang-orang dalam bekerjasama atau mengkoordinasikan usaha-usahanya untuk mencapai tujuan organisasi.

\subsection{Pengaruh Kecerdasan Emosional Terhadap Kinerja Pegawai}

Hasil penelitian menemukan bahwa secara parsial adanya pengaruh positif signifikan antara kecerdasan emosional terhadap kinerja pegawai. Hal ini berarti bahwa setiap adanya peningkatan yang terjadi pada kecerdasan emosional pegawai maka kinerja pegawai akan mengalami peningkatan atau adanya hubungan searah.

Hasil penelitian ini sejalan beberapa penelitian terdahulu yang mengemukakan adanya pengaruh positif signifikan antara kecerdasan emosional terhadap kinerja pegawai. Menurut Carmeli (2003) dalam (Yozgat, Yurtkoru, \& Bilginoğlu, 2013) menyatakan bahwa pegawai dengan tingkat kecerdasan yang tinggi dapat mengelola emosi mereka dalam hal mempertahankan keadaan mental yang positif yang dapat menyebabkan peningkatan kinerja pekerjaan.

Hal ini sejalan dengan uraian yang dikemukakan oleh Setyaningrum, Utami, \& Ruhana (2016) bahwa kecerdasan emosional yang baik akan membuat seseorang mampu membuat keputusan yang tegas dan tepat walaupun dalam keadaan tertekan. Kecerdasan emosional juga membuat seseorang dapat menunjukkan integritasnya.Orang dengan kecerdasan emosional yang baik mampu berpikir jernih walaupun dalam tekanan, bertindak sesuai etika, berpegang pada prinsip dan memiliki dorongan berprestasi. Lebih lanjut diuraikan bahwa hubungan antara kecerdasan emosional terhadap kinerja dapat dicerminkan berdasarkan hubungannya dengan lima komponen dalam kecerdasan emosional yakni kesadaran diri, pengaturan diri, motivasi, empati dan keterampilan sosial.

Adanya pengaruh positif signifikan antara kecerdasan emosional dan kinerja pegawai pada Dinas Dinas Sumberdaya Air Bina Marga Provinsi Sulawesi Tenggara mengindikasikan bahwa mayoritas para pegawai yang bekerja di Dinas Sumberdaya Air Bina Marga Provinsi Sulawesi Tenggara, memiliki kecerdasan emosional yang sudah cukup baik atau dalam kata lain pegawai telah mampu untuk 
mengendalikan secara penuh emosionalnya dalam bekerja. Hal ini dimungkinkan pula karena pegawai yang bekerja pada Dinas Sumberdaya Air Bina Marga Provinsi Sulawesi Tenggara, merupakan pegawaipegawai dengan klasifikasi umur yang sudah cukup dewasa yakni berkisar antara $25-40$ Tahun keatas, sehingga dengan usia ini, pegawai juga telah memiliki kemampuan untuk mengontrol emosinya yang dimiliki khususnya dalam bekerja.

Sejalan dengan uraian tersebut, menurut Goleman (2005) mengemukakan bahwa faktor internal yang mempengaruhi kecerdasan emosional yaitu faktor yang berasal dari dalam diri yang dipengaruhi oleh keadaan otak seseorang. Seperti halnya dengan yang diuraikan oleh Khalifah (2009) bahwa bagianbagian otak yang memungkinkan merasakan emosi rusak maka kemampuan rasional (intelek) tetap utuh. Ketika seseorang dalam kondisi traumatis dengan rusaknya otak emosi, maka ia masi dapat berbicara, menganalisa bahkan dapat memprediksi bagaimana ia harus bertindak dalam situasi. Tapi dalam keadaan tragis tidak demikian dapat berinteraksi dengan orang lain secara layak sehingga rencana yang telah disusun tidak dapat dijalankan dan kesuksesan jauh darinya.

\section{Kesimpulan}

Penelitian ini memberikan kesimpulan bahwa kinerja pegawai berhubungan erat dengan organisasi. Setiap organisasi ingin mempunyai pegawai yang terbaik guna memajukan kinerja organisasi. Seorang pegawai yang memiliki kinerja yang tinggi dan baik dapat menunjang tercapainya tujuan dan sasaran yang telah ditetapkan oleh perusahaan. Untuk dapat memiliki kinerja yang tinggi dan baik, seorang pegawai dalam melaksanakan pekerjaannya harus memiliki kemampuan dan keterampilan yang sesuai dengan pekerjaan yang ditekuninya. Salah satunya adalah kemampuan komunikasi dan kecerdasan emosional pegawai.

Penelitian ini memberikan implikasi bahwa kinerja pegawai yang tinggi dapat tercapai jika adanya dukungan dari komunikasi dan kecerdasan emosional pegawai yang baik. Semakin baiknya komunikasi dan kecerdasan emosional yang dimiliki oleh pegawai maka semakin baik pula pencapaian kinerja pegawai yang pada akhirnya mampu mendorong pencapaian kinerja organisasi yang baik pula.

\section{Daftar Pustaka}

Anwar Prabu, M. (2017). Manajemen Sumber Daya Manusia Perusahaan, Bandung: PT. Remaja Rosdakarya.

Drejer, A. (2001). Illustrating Competence Development. Measuring Business Excellence. https://doi.org/10.1108/13683040110397 293

Duwit, F. (2015). Pengaruh Kompetensi Komunikasi, Kecerdasan Emosional dan Budaya Organisasi Terhadap Kinerja Pegawai (Studi Pada Badan Pemberdayaan Masyarakat dan Pemerintahan Kampung Kabupaten Raja Ampat Propinsi Papua Barat). Universitas Sam Ratulangi Manado, 3(4), 130-141.

Femi, A. F. (2014). The Impact of Communication on Workers'

Performance in Selected Organisations in Lagos State, Nigeria. IOSR Journal of Humanities and Social Science. https://doi.org/10.9790/0837-19827582

Flippo, E. B. (2009). Humam Resource Management. Academy of Management Journal.

Goleman, D. (2005). Emotional Intelligence. Leadership.

Ismuhadjar. (2006). Pengaruh Motivasi Kerja, Komunikasi antar Pribadi dan Komitmen Organisasi Terhadap Kinerja Pejabat Struktural dan Dosen Tetap di Beberapa Perguruan Tinggi Swasta di Jakarta. https://doi.org/10.14710/jbs.15.2.52-61

Kahtani, A. Al. (2013). Employee Emotional Intelligence and Employee Performance in the Higher Education Institutions in Saudi Arabia: A Proposed Theoretical Framework. International Journal of Business and Social Science.

Katz, D., \& Kahn, R. L. (1978). Organizations and The System Concept. Classics of Organization Theory.

Lakoy, A. C. (2015). Pengaruh Komunikasi, Kerjasama Kelompok dan Kreativitas Terhadap Kinerja Karyawan Pada Hotel Aryaduta Manado. Jurnal EMBA.

Naseer, Z., Chishti, S.-H., Rahman, F., \& 
Jumani, N. (2011). Impact of Emotional Intelligence on Team Performance in Higher Education Institutes. International Online Journal of Educational Sciences.

Panuju, R. (2001). Komunikasi Organisasi: Dari Konseptual-Teoritis ke Empirik.

Pudhag Wangi, W. G., \& Faslah, R. (2013). Pengaruh Komunikasi Antarpribadi dan Kecerdasan Emosional Terhadap Kinerja pada Karyawan di PT. Asuransi Raya. Econosains Jurnal Online Ekonomi Dan Pendidikan. https://doi.org/10.21009/econosains.0111. 09

Robbins, S. P., \& Judge, T. A. (2008). Perilaku Organisasi Jilid II. Salemba Empat. https://doi.org/10.1097/ACM.0b013e318 $21 \mathrm{db} 670$

Romantik, C. I. dan H. E. (2014). Pengaruh Kecerdasan Emosional, Komunikasi, dan Lingkungan Kerja terhadap Kinerja Pegawai Negeri pada Kantor Pelayanan Publik di Kabupaten Purbalingga. Media Ekonomi Universitas Muhammadiyah Purwokerto, 2(16), 77-87.

Sani, A. (2012). Analisis Pengaruh Burnout dan Kecerdasan Emosional (EI) Terhadap Kinerja Pegawai PT Bank Mega Syari'ah Cabang Malang. Iqtishoduna. https://doi.org/10.18860/iq.v0i0.1743

Scudder, J. N., \& Guinan, P. J. (1989). Communication Competencies as Discriminators of Superiors' Ratings of Employee Performance. Journal of Business Communication. https://doi.org/10.1177/00219436890260 0302

Setyaningrum, R., Utami, H., \& Ruhana, I. (2016). Pengaruh Kecerdasan Emosional
Terhadap Kinerja (Studi Pada Karyawan PT. Jasa Raharja Cabang Jawa Timur). Jurnal Administrasi Bisnis S1 Universitas Brawijaya, 36(1), 211-220.

Susi Hendriani, Yulia Efni, R. (2013). Kecerdasan Emosional, Komunikasi, Komitmen dan Kinerja Pegawai. Universitas Riau, 57-66.

Trihandini, Fabiola Meirnayati. (2005). Pengaruh Kecerdasan Emosional Terhadap Kinerja Keryawan yang Dimediasi oleh Stres Kerja dan Dimoderasi oleh Religiusitas pada PT Perkebunan Nusantara IV.pdf.

Wong, C. S., \& Law, K. S. (2002). The Effects of Leader and Follower Emotional Intelligence on Performance and Attitude: An Exploratory Study. Leadership Quarterly. https://doi.org/10.1016/S10489843(02)00099-1

Wursanto, I. (2003). Dasar-dasar Ilmu Organisasi. Yogyakarta: Andi. https://doi.org/10.1038/cddis.2011.1

Yakub, S., Gunawan, R., \& Halim, J. (2015). Pengaruh Kemampuan Komunikasi dan Kecerdasan Emosional Terhadap Kinerja Karyawan pada PT. Perkebunan Nusantara I (Persero) Aceh. Jurnal Ilmiah SAINTIKOM.

Yozgat, U., Yurtkoru, S., \& Bilginoğlu, E. (2013). Job Stress and Job Performance Among Employees in Public Sector in Istanbul: Examining the Moderating Role of Emotional Intelligence. Procedia Social and Behavioral Sciences. https://doi.org/10.1016/j.sbspro.2013.04.0 56 